\title{
Effects of particulate matter under behavioral, hematological and biochemical parameters in Wistar rats
}

Samanta Cristina-Siebel-de-Moraes ${ }^{1}$, Victória Branca Moron ${ }^{1}$, Aline Belem-Machado ${ }^{1}$, Paula Schmitt ${ }^{1}$, Daniela Montanari-Migliavacca-Osorio² \& Daiane Bolzan-Berlese ${ }^{1}$

1 Department of Biochemistry, Post-Graduation Program in Environmental Quality, Feevale University, Brazil.

2 Department of Chemistry, Post-Graduation Program in Environmental Quality, Feevale University, Brazil.

Correspondence

A. Belem-Machado

E-mail: linebmachado@hotmail.com

Received: 2 September 2019

Accepted: 2 June 2020

Published on-line: 29 June 2020

\section{Resumen}

Efectos del material particulado en los parámetros de comportamiento, hematológicos y bioquímicos en las ratas Wistar

El Material Particulado (MP) puede alterar los procesos cognitivos, el comportamiento depresivo y hematológico en el modelo animal. El objetivo fue evaluar los efectos causados por MP en los parámetros conductuales, hematológicos y bioquímicos en un modelo animal. Se observaron alteraciones en la actividad locomotora de las ratas, donde hubo una disminución significativa en la locomoción del Grupo 3 ( $\left.\mathrm{MP}_{10}\right)$ en comparación con los Grupo 1 (Control) y Grupo $2\left(\mathrm{MP}_{2,5}\right)$. Con respecto al comportamiento de ansiedad, el Grupo 3 pasó significativamente más tiempo en brazos abiertos en comparación con el control y $\mathrm{MP}_{2,5}$. No se observaron cambios hematológicos y bioquímicos. En este estudio, se concluye que, la exposición a la MP puede causar daño neurológico y, en consecuencia, afectar a otros sistemas.

Palabras clave: Hematología; Contaminación del aire; Pruebas de comportamiento; Bioquímica.

\begin{abstract}
Particulate matter (PM) can alter the cognitive processes, the depressive behavior, and the hematological profile in animals. This study aimed to evaluate the effects on behavioral, hematological, and biochemical parameters caused by PM in an animal model. A significant decrease in the locomotion activity of Group $3\left(\mathrm{PM}_{10}\right)$ in relation to Group 1 (Control) and Group $2\left(\mathrm{PM}_{2.5}\right)$ was observed. Regarding the anxiety behavior, Group 3 remained significantly the most part of the time in the open arms when compared to the control and $\mathrm{PM}_{2.5}$ groups. No hematological or biochemical alterations were observed among groups. In this study, we concluded that the exposure to particulate matter can cause neurological damages, and consequently, affect other systems.
\end{abstract}

Key words: Hematology; Atmospheric pollution; Behavioral tests; Biochemistry 


\section{Introduction}

Particulate matter (PM) is the most noticeable pollutant in the atmosphere, being referred to as a consolidation of atmospheric particles. Aerosols, in solid or liquid form, are particles suspended in the air, found in urbanized centers, industrial poles, and highways (Seinfeld \& Pandis 2006, Nicodemos et al. 2009, Chithra \& Nagendra 2013, Manahan 2013).

Particulate matter is classified according to its size and shape in total suspended particles (TSP), smoke, and inhalable particulates (IP). They are divided into coarse inhalable particles $\left(\mathrm{PM}_{10}\right)$, with aerodynamic diameter between $2.5 \mu \mathrm{m}$ and $10 \mu \mathrm{m}$, and fine inhalable particles $\left(\mathrm{PM}_{2.5}\right)$, with aerodynamic diameter up to $2.5 \mu \mathrm{m}$. The IP acts as catalysts because they increase the speed of the chemical reactions, transforming the primary pollutants into secondary pollutants, which is harmful (Mello et al. 2010, Guerra \& Miranda 2011).

The smaller particles $(2.5 \mu \mathrm{m})$ are derived from the combustion of mobile sources, such as vehicles, and stationary, or fixed sources, such as industries. Carbon, lead, vanadium, bromine, sulfur, and nitrogen oxides are the main pollutants of this fine particle fraction. Carbon monoxide (CO), carbon dioxide $\left(\mathrm{CO}_{2}\right)$, and water are the result of biomass burning, which at the final stage releases products from the incomplete combustion, such as organic particles, also present in the PM (Donaldson et al. 2001).

The differential of PM is characterized by the transport of gases aspirated on the surface that migrate to the distant points of the respiratory tract, responsible for the gas exchange in the lungs. When the particles are settled in the upper respiratory tract, the body's defense system is activated and tries to remove it through mechanisms such as sneezing, caused by macroparticles that do not pass beyond the nasal orifice due to their size. As for the particles that reach the lower respiratory system, the defense mechanism is through coughing (Braga et al. 2001).

The effects of the exposure to particulate matter also affect the cardiac system, manifesting through alterations such as a change in heart rate, myocardial ischemia, ineffective blood coagulation, increased oxidative stress, and inflammatory induction (Fernandes et al. 2010). Demonstrating that the inflammatory process after the exposure to atmospheric pollution is a potent mechanism associated with metabolic alterations.

The open field test is the most used test to analyze the animal's behavior to a certain chemical, which evaluates the locomotor and rearing of the animal. These are also the most sensitive responses to prolonged or repeated exposures (Rojas-Carvajal et al. 2018). The elevated plus maze test is another behavior test and is widely used to evaluate the anxiety behavior in rats. The test is based on the number of entries in the closed (protection site) and open (unprotection site) arms of the apparatus, in which it is assumed that the animal approaches or avoids conflict, respectively (Carobrez \& Bertoglio 2005).

Therefore, the present study aimed to evaluate the effects caused by the coarse and fine particulate matter on behavioral, hematological, and biochemical parameters in male Wistar rats.

\section{Materials and methods}

\section{Particulate matter}

The particulate matter used in this research was collected in 2017, from the metropolitan area of Porto Alegre, in the municipalities of São Leopoldo and Canoas/RS - Brazil. Sample collections occurred once a month at each collection point for 6 months. The precise geographical coordinates are expressed in table 1 , with a justification of the locations, the points are shown in the map of figure 1 .

\begin{tabular}{|c|c|c|c|}
\hline $\begin{array}{l}\text { Sampling } \\
\text { points }\end{array}$ & Municipality & $\begin{array}{c}\text { Geographical } \\
\text { coordinates }\end{array}$ & Justification \\
\hline Point 1 & São Leopoldo & $\begin{array}{c}-29^{\circ} 46^{\prime} 19,01^{\prime \prime} \\
-51^{\circ} 9^{\prime} 7,17^{\prime \prime}\end{array}$ & $\begin{array}{l}\text { Urban area. Estimated population at } 225.5 \text { thousand } \\
\text { inhabitants and demographic density of } 2083,8 \text { inhabitants per } \\
\mathrm{km}^{2} \text {. Point located approximately } 200 \mathrm{~m} \text { from BR } 116 \text {. }\end{array}$ \\
\hline Point 2 & Canoas & $\begin{array}{l}-29^{\circ} 55^{\prime} 19,79 " \\
-51^{\circ} 10^{\prime} 43,05^{\prime \prime}\end{array}$ & $\begin{array}{l}\text { Urban area. Estimated population at } 338.5 \text { thousand } \\
\text { inhabitants and demographic density of } 2470,1 \text { inhabitants per } \\
\mathrm{km}^{2} \text {. Point located approximately } 60 \mathrm{~m} \text { from BR } 116 \text {. }\end{array}$ \\
\hline
\end{tabular}

Tabla 1. Localización y descripción de los puntos de muestreo de MP.

Table 1. Localization and description of the sampling points of PM. 

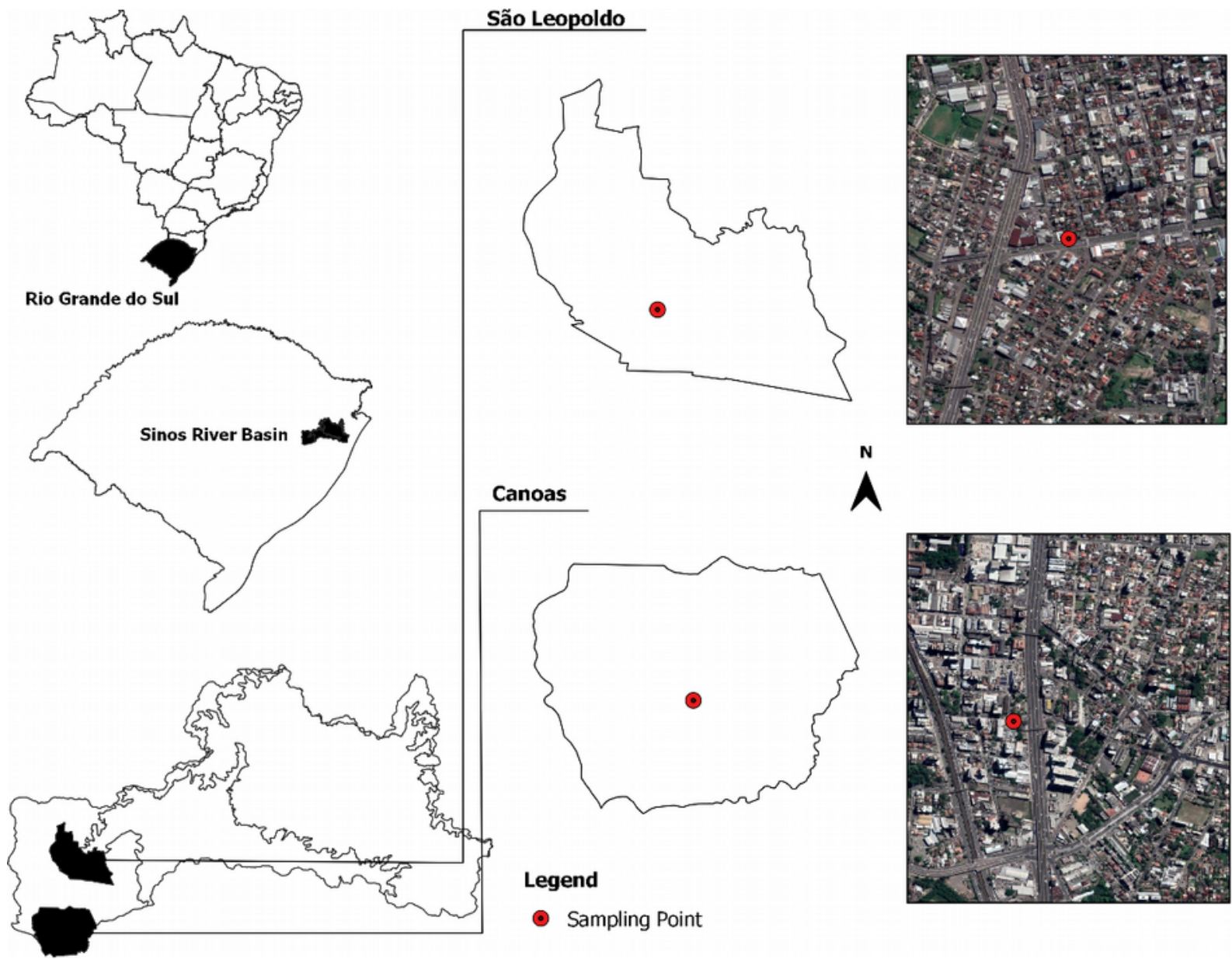

A

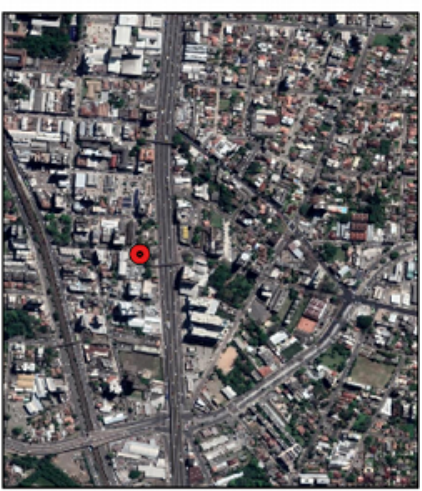

Figura 1. Mapa de los puntos de muestreo en São Leopoldo y Canoas.

Figure 1. Map with the sampling points in São Leopoldo and Canoas.

The PM samples were collected monthly, by a period of 24 hours, from January to July 2017 (Summer until Winter), according to the Protocol for Collection of Atmospheric Particulate Matter from the National Institute for Space Research (INPE 2012). The atmospheric particles, fine and coarse, were collected utilizing a fine and coarse matter sampler Stacked Filter Unit (SFU) (Maenhaut et al. 1993, Hopke et al. 1997) in which the quartz or borosilicate filters were placed in series, allowing the separation of particles into two bands of size (particles with a diameter between $10 \mu \mathrm{m}$ and $2.5 \mu \mathrm{m}$ and particles smaller than $2.5 \mu \mathrm{m}$ ).

\section{Quantification of metal elements in $\mathbf{P M}_{2.5-10}$ and $\mathbf{P M}_{2.5}$}

The metals (Al, $\mathrm{Cd}, \mathrm{Pb}, \mathrm{Cu}, \mathrm{Cr}, \mathrm{Fe}, \mathrm{Mn}$, and $\mathrm{Ni}$ ) were quantified by graphite furnace atomic absorption spectrometry (ZEEnit 600, Analytik Jena $A G)$ and $\mathrm{Zn}$ was determined by flame atomic absorption spectrometry (SpectrAA 110, Varian) in the solubilized fractions of $\mathrm{PM}_{2.5-10}$ and $\mathrm{PM}_{2.5}$.

\section{Animal model}

For the animal model protocol, adapted from the protocol of Unsal et al. (2018) and Binoki (2010), thirty male Wistar rats were used $( \pm 250$ grams) from Feevale University Vivarium. The animals were exposed to a 12 hours light/dark cycle in a climatized and humidified room $\left(22 \pm 1{ }^{\circ} \mathrm{C}\right.$ and 50 $\pm 10 \% \mathrm{RH})$. The animals received water ad libitum and a reference industrialized food for rats (Nuvilab CR1-Nuvital ${ }^{\circledR}$ ). The rats were randomly divided into 3 groups composed of 10 rats each. Control Group: animals submitted to the instillation of $50 \mu \mathrm{l}$ of distilled water in each nostril. Group $\mathrm{PM}_{10}$ : animals submitted to the instillation of $50 \mu \mathrm{l}$ of an aqueous suspension of $\mathrm{PM}_{10}$ in each nostril. Group $\mathrm{PM}_{2.5}$ : animals submitted to the instillation of $50 \mu \mathrm{l}$ of an aqueous suspension of $\mathrm{PM}_{2.5}$ in each nostril. The experiment was performed during 8 consecutive weeks of nasal instillations of distilled water, or $\mathrm{PM}_{10}$, or $\mathrm{PM}_{2.5}$. During each week three interventions were promoted on alternate days. A calibrated micropipette was 
used for the nasal instillations. Thus, the animals were submitted to behavioral, hematological, and biochemical analyses (Binoki 2010).

The animal model protocol was approved by the Ethics Committee for Animal Research of Feevale University under the number 01.14.027.

\section{Behavioral parameter analysis}

Determination of locomotor parameters: the open field test (OFT) consists of placing the animals in the left posterior quadrant of the arena of the open

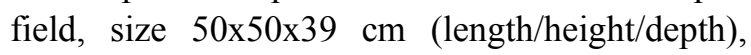
with high walls, white plywood, and a frontal glass wall. The field floor is divided into 12 equal quadrants by black lines. The animal is placed in the right corner, then the test occurs for 5 minutes. The number of times the animal crosses the black lines (crossings=locomotor response) and the number of times the rat rises on its rear paws (rearings=exploratory response) were registered as long as the free exploration of the environment was allowed. The fecal bolus corresponds to the number of animal feces for 5 minutes. After the test with each animal, the box was sanitized with $30 \%$ alcohol to prevent that the urine and feces smell interfere in the test. An observer, blind to the experimental condition of the experimental animal, recorded the behavioral data using the protocol described above (Nahas 1999).

Determination of anxiety parameters: the elevated plus maze test (EPM) is formed by 4 opposed and elevated arms. Two arms have walls, being called closed arms $(40 \times 40 \times 10 \mathrm{~cm})$. The other two arms do not have walls, being called open arms (40x10 cm, with acrylic side edges of 1 $\mathrm{cm}$ height). The maze was placed $50 \mathrm{~cm}$ from the floor. The use of maze is based on the natural aversion of the rats to open fields. The number of entries and time spent on the open arms are used as indicators regarding the anxiety, the more intense the exploration of the open arms, the smaller the anxiety. The rodents remained in the EMP for 5 minutes, and the sessions were registered concomitantly. When the experiment started, the rats were always placed in the center of the maze with its head facing one of the open arms. After, the time spent and the total numbers of entries on the open and closed arms were analyzed. The entry was registered when the animal placed its four paws inside one of the arms. An observer, blind to the experimental condition of the experimental animal, recorded the behavioral data using the protocol described above (Hogg 1996).

\section{Biochemical and hematological parameters analysis}

After the behavioral evaluation, the animals were anesthetized and sacrificed by guillotine for the blood sample collections. The biochemical parameters were glycemia, total cholesterol, HDL, and triglycerides, and the hematological parameters were erythrocytes, hemoglobin, hematocrit, MCV, $\mathrm{MCH}, \mathrm{MCHC}$, leukocytes, platelets, segmented, monocytes, and lymphocytes.

\section{Statistical analysis}

For the data analysis, descriptive statistics were initially used, followed by non-parametric tests due to the non-normality of the data (KOLMOGOROV-SMIRNOV test). For the comparison of data between two properties, the ANOVA test was performed followed by the Tukey test, in which $\mathrm{p}<0.05$ was considered significantly different. Data were processed in the Statistical Package for the Social Sciences Software (SPSS), version 24.0.

\section{Results and Discussion}

\section{Particulate Matter}

The fine and coarse particulate matter were collected from January to July 2017, totalizing 24 samples, 12 for the fine PM, and 12 for the coarse $\mathrm{PM}$. The collections were performed on non-rainy days.

The figure 2 presents the concentrations of $\mathrm{PM}_{2,5-10}$ and $\mathrm{PM}_{2,5}$ detected at São Leopoldo and Canoas (Figs. 2a and $2 \mathrm{~b}$ ) sampling points, as well as the indications of international air quality standard (United States Environmental Protection Agency [US EPA] and European Commission [EC]) for $\mathrm{PM}_{2.5}$ (24 hours). The results demonstrated that $\mathrm{PM}_{2.5-10}$ exceeded the quality standards in all samples, except for July 2017. However, $\mathrm{PM}_{2.5}$ only exceed the quality standards in January and February 2017 at São Leopoldo (Fig. 2a). Similar behavior was observed for the $\mathrm{PM}_{2.5-10}$ from Canoas, which did not exceed the quality standards only in March and July 2017. And the $\mathrm{PM}_{2.5}$ was exceeded only in April 2017. 

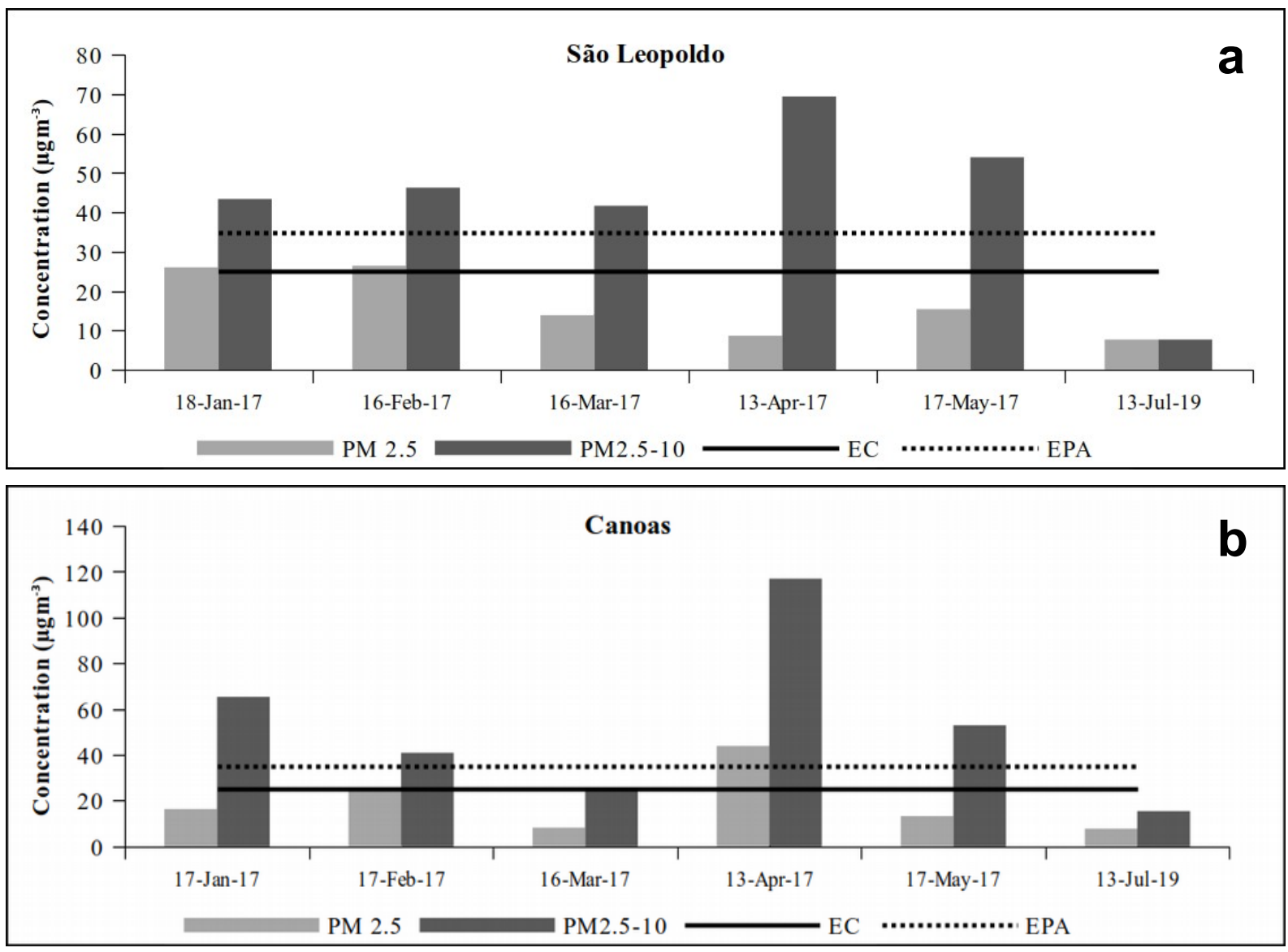

Figura 2. Concentraciones de $\mathrm{MP}_{2.5-10}$ y $\mathrm{MP}_{2.5}$ en los puntos de muestreo. a: São Leopoldo; b: Canoas. EC: Comisión Europea; EPA: Agencia de Protección Ambiental.

Figure 2. $\mathrm{PM}_{2.5-10}$ and $\mathrm{PM}_{2.5}$ concentrations in the sampling points. a: São Leopoldo; b: Canoas. EC: European Commission; EPA: Environmental Protection Agency.

The mean concentrations and standard deviation (SD) of $\mathrm{PM}_{2.5-10}$ and $\mathrm{PM}_{2.5}$ at São Leopoldo sampling point were $43.76(\mathrm{SD}=20.37)$ and 16.37

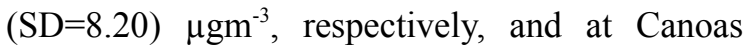
sampling point were $52.67(\mathrm{SD}=36.37)$ and 18.97 $(\mathrm{SD}=13.66){\mu \mathrm{gm}^{-3}}^{-3}$, respectively.

\section{Metal elements in $\mathbf{P M}_{2.5-10}$ and $\mathbf{P M}_{2.5}$}

Table 2 presents the mean concentrations of metal elements found in $\mathrm{PM}_{2.5}$ and $\mathrm{PM}_{2.5-10}$. The elements $\mathrm{Al}$ and Fe presented the highest concentrations among the metal elements analyzed for the study period. The elements $\mathrm{Cd}, \mathrm{Ni}$, and $\mathrm{Cr}$ presented below the limits of quantification of the analysis method.

The metallic elements $\mathrm{Al}, \mathrm{Fe}$, and $\mathrm{Mn}$ are constituents of Earth's crust and occur naturally in the PM through the resuspension of the soil (Alleman et al. 2010, Loyola et al. 2012, Alves et al. 2015), although anthropogenic activities, such as metal smelting and the construction, can contribute to the increase of the levels of these elements in the atmosphere (Hieu \& Lee 2010, Lim et al., 2010). $\mathrm{Pb}$ is considered toxic and usually related to the fine fraction of PM (Espinosa et al. 2001). Xu et al. (2012) related vehicular emissions as one of the main sources of $\mathrm{Pb}$ in the environment, even after the prohibition of the use of compounds of this element as an additive in gasoline. Migliavacca et al. (2012) identified that the occurrence of $\mathrm{Pb}$ in the metropolitan region of Porto Alegre, Southern Brazil, is associated with a combination of two anthropogenic sources: siderurgy/smelting activity and vehicular emissions. $\mathrm{Zn}$ is used as zinc oxide $(\mathrm{ZnO})$ by the rubber industry in the tire vulcanization process, therefore, the presence of $\mathrm{Zn}$ in areas influenced by vehicular traffic can be associated with tire wear (Adachi \& Tainosho 2004, Thorpe \& Harrison 2008, Alleman et al. 2010, Loyola et al. 2012). The $\mathrm{Cu}$ can be emitted through burning and improper disposal of solid 


\begin{tabular}{|c|c|c|c|c|c|}
\hline & \multirow{2}{*}{ Metals } & \multicolumn{4}{|c|}{ Canoas } \\
\hline & & Mean & Median & Minimum & Maximum \\
\hline & $\mathrm{Al}$ & 320.97 & 321.49 & 132.90 & 508.00 \\
\hline & $\mathrm{Pb}$ & 16.72 & 14.78 & 1.53 & 35.80 \\
\hline $\mathrm{PM}_{2.5}$ & $\mathrm{Cu}$ & 14.06 & 13.44 & 3.35 & 26.03 \\
\hline & $\mathrm{Fe}$ & 304.72 & 8.13 & 1.25 & 1201.38 \\
\hline & $\mathrm{Mn}$ & 9.79 & 2.79 & 0.06 & 33.54 \\
\hline & $\mathrm{Zn}$ & 23.98 & 16.47 & 4.95 & 58.05 \\
\hline & $\mathrm{Al}$ & 873.26 & 502.75 & 322.28 & 2165.27 \\
\hline & $\mathrm{Pb}$ & 2.88 & 1.53 & 1.44 & 7.01 \\
\hline & $\mathrm{Cu}$ & 39.14 & 33.54 & 18.32 & 71.16 \\
\hline $\mathrm{PIV}_{2.5-10}$ & $\mathrm{Fe}$ & 363.12 & 77.95 & 1.25 & 1295.34 \\
\hline & $\mathrm{Mn}$ & 7.41 & 3.45 & 0.27 & 22.48 \\
\hline & $\mathrm{Zn}$ & 24.13 & 21.88 & 5.79 & 46.99 \\
\hline
\end{tabular}

\begin{tabular}{|cccc|}
\hline \multicolumn{4}{|c|}{ São Leopoldo } \\
Mean & Median & Minimum & Maximum \\
\hline 5736.52 & 829.15 & 9.32 & 21278.46 \\
32.90 & 23.53 & 1.44 & 83.09 \\
18.01 & 16.70 & 4.18 & 34.44 \\
495.79 & 286.52 & 71.79 & 1338.32 \\
8.41 & 4.66 & 0.27 & 24.06 \\
52.00 & 64.28 & 5.79 & 73.65 \\
\hline \multicolumn{4}{c}{} \\
\hline 854.48 & 296.43 & 181.59 & 2643.48 \\
4.78 & 2.87 & 1.30 & 12.06 \\
23.26 & 15.67 & 1.05 & 60.64 \\
35.99 & 36.49 & 1.25 & 69.75 \\
7.18 & 7.70 & 0.27 & 13.06 \\
68.82 & 78.95 & 0.81 & 116.55 \\
\hline
\end{tabular}

Tabla 2. Estadística descriptiva de $\mathrm{MP}_{2.5} \mathrm{Y} \mathrm{MP}_{2.5-10} \mathrm{y}$ concentraciones de elementos metálicos $\left(\mathrm{ng} \mathrm{m}^{-3}\right)$ determinadas en las muestras recolectadas en Canoas y São Leopoldo. $\mathrm{n}=12$.

Table 2. Descriptive statistics of $\mathrm{PM}_{2.5}$ and $\mathrm{PM}_{2.5-10}$ and metallic element concentrations ( $\mathrm{ng} \mathrm{m}^{-3}$ ) determined in the samples collected at Canoas and São Leopoldo. $\mathrm{n}=12$.

\begin{tabular}{llll}
\hline & Crossing & Rearing & Fecal Bolus \\
\hline Group 1 (Control) & $58.20 \pm 12.22$ & $18.60 \pm 6.75$ & $3.80 \pm 2.20$ \\
Group 2 $\left(\mathrm{PM}_{2.5}\right)$ & $52.10 \pm 9.51$ & $18.40 \pm 6.24$ & $2.90 \pm 2.18$ \\
Group 3 $\left(\mathrm{PM}_{10}\right)$ & $39.60 \pm 10.58^{*}$ & $13.00 \pm 8.52$ & $2.40 \pm 1.50$ \\
\hline
\end{tabular}

Tabla 3. Resultados de campo abierto. Los datos se expresan como media \pm desviación estándar. $n=10$ animales por grupo. $* p<0.05$ ANOVA seguido de la prueba de Tukey. *Diferencia significativa $(\mathrm{p}<0,05)$ del grupo 3 versus grupo 1 y grupo 2 , para actividad locomotora. Table 3. Open Field Results. Data are expressed as mean \pm standard deviation. $n=10$ animals per group. * $p<0.05$ ANOVA followed by Tukey test. *Group 3 differs from group 1 and group 2 for locomotor activity.

waste, and by burning fossil fuel (Kabata-Pendias \& Mukherjee 2007).

\section{Open Field}

After 8 weeks of nasal instillation, the animals were submitted to the behavioral tests. Table 3 presents the results obtained from the open field test, which evaluated the locomotor activity (crossing), exploratory (rearing), and fecal bolus.

According to table 3 , a significant difference between the group that received $\mathrm{PM}_{10}$ in relation to the Control Group and Group $\mathrm{PM}_{2.5}$ can be observed. The data demonstrated that Group $\mathrm{PM}_{10}$ had a smaller locomotor activity in relation to the Control and $\mathrm{PM}_{2.5}$ groups. There was no significant difference regarding the exploratory activity (rearing) and fecal bolus.

The coarse fraction of the particulate matter is the fraction that is retained on the upper airways, which can be eliminated through physiological mechanisms such as a sneeze or nasal cleaning. When the particles of this particulate matter are not totally eliminated or removed, the risk of exposure increases, and consequently the damages increase as well. The particles of the particulate matter can have some different paths when they remain in the organism, where they can escape from the reticuloendothelial system (Wang et al.
2017), and be deposited in the lungs and be phagocyted by alveolar macrophages, which can trigger an inflammatory response, including the release of cytokines (Luo et al. 2017). Some particles can transit through the epithelial barrier and reach the blood circulation or reach the Central Nervous System (CNS) (Wang et al. 2017).

Studies performed by Costa et al. (2017) in adult mice demonstrated that the exposure to particulate matter, even in low amounts, can cause damages to the CNS, such as neurotoxicity and neuroinflammation, even though it has not been elucidated how these mechanisms occur (Block \& Calderón-Guarcidueñas 2009). These damages on the CNS can lead to cognitive, neuroinflammatory, and neurodegenerative alterations.

Our experiment corroborates to the study abovementioned, considering that the decrease in the locomotor activity may have been influenced by the contact with the particulate matter, affecting mainly the region of the brain responsible for walking or locomotion.

\section{Elevated Plus Maze}

According to the data shown in table 4, regarding the anxiety behavior evaluated in the elevated plus maze test, a significant difference was observed in relation to the time spent in the open and closed 


\begin{tabular}{lccccc}
\hline & No. E in open & T in open & No. E in closed & T in closed & Rearing \\
\hline Group 1 $(\mathrm{CTL})$ & $2.5 \pm 1.0$ & $84.8 \pm 58$ & $2.5 \pm 0.7$ & $218.6 \pm 53$ & $5.2 \pm 3.0$ \\
Group 2 $(\mathrm{PM} 2.5)$ & $2.7 \pm 1.3$ & $116.5 \pm 36.5$ & $3.0 \pm 1.7$ & $155.2 \pm 52.5$ & $8.0 \pm 4.5$ \\
Group 3 $\left(\mathrm{PM}_{10}\right)$ & $3.5 \pm 1.50$ & $143.6 \pm 40.8 *$ & $3.5 \pm 1.6$ & $151.8 \pm 39.4$ & $7.9 \pm 4.7$ \\
\hline
\end{tabular}

*Group 3 differs from Group 1 only in $\mathrm{T}$ in open ( $<<0.05$, ANOVA followed by Tukey test)

Tabla 4. Resultados del laberinto elevado. No. E in open: número de entradas en los brazos abiertos; T in closed: Tiempo pasado en los brazos abiertos; No. E in closed: número de entradas en los brazos cerrados. T in closed: tiempo pasado en los brazos cerrados. Los datos se expresan como media \pm desviación estándar; tiempo $(\mathrm{T})$ en segundos. $\mathrm{n}=10$ animales por grupo.

Table 4. Elevated Plus Maze Results. No. E in open: number of entries in the open arms; T in open: Time spent in the open arms. No. E in closed: number of entries in the closed arms. $\mathrm{T}$ in closed: time spent in the closed arms. Data are expressed as mean \pm standard deviation. Time ( $\mathrm{T})$ is expressed as seconds. $\mathrm{n}=10$ animals per group.

arms. In the other parameters, no statistical differences were noted. Control Group stayed more time in the closed arms and less time in the open arms when compared to Group $\mathrm{PM}_{10}$. These data demonstrate that the animals that received nasal instillation of $\mathrm{PM}_{10}$ appeared to be less anxious in relation to the control and $\mathrm{PM}_{2.5}$ groups. However, this characteristic can be associated with the decrease in the locomotor activity, as shown in table 3.

The modulation of anxiety, pain, and emotion is related to the periaqueductal gray matter (PGM), which is a brain area located in the mesencephalon of mammals (Keay \& Bandler 2004). Regarding its function, studies in vivo were performed and demonstrated that the PGM is related to anxiety, besides maintaining the cardiovascular and respiratory system in homeostasis; because it is not a structure that works homogeneously, it is divided into different subregions capable of controlling the markers abovementioned (Depaulis \& Bandler 1991, Carrive 1993, Behbehani 1995, Keay \& Bandler 2004, Benarroch 2012, Carrive \& Morgan 2012, Linnman et al. 2012, Holstege 2014).

The results of this experiment differ from other studies performed by the authors abovementioned, which demonstrate that the rats, when exposed to the elevated plus maze test, presented a high level of anxiety, remaining more time in the closed arms. The exposure to particulate matter causes respiratory damages, and possibly the decrease of the anxiety is associated with the fact that the rodents decreased their locomotor activity, spending more time in the open arms. This decrease in the locomotor activity may be related to neuroinflammation and neurodegeneration of the CNS, associated with the periaqueductal gray matter, in which one of its functions is to control the respira- tion in mammals, resulted in the uncontrolled respiratory function, caused by the instillation of the particulate matter. Thus, to remain in the open arms seems to be associated with a congested airway, in which the rats attempt to obtain a better respiratory pattern.

Alterations in the respiratory pattern are in agreement with studies performed by MazzoliRocha et al. (2014), which demonstrated that intranasal instillations of particulate matter, when repeated, cause an alveolar collapse and pulmonary bronchoconstriction, making breathing difficult corroborating with studies conducted by Dubowsky et al. (2006), which affirms that the pulmonary inflammation is linked to air pollution, causing an imbalance in the autonomous system, activating the sympathetic nervous system, and modifying the respiratory pattern.

\section{Hematological Parameters}

In this study, no significant alterations were observed regarding the hematological and biochemical parameters (Table 5), although there was evidence that the particles from the particulate matter reached the cardiovascular system through inflammatory mediators produced by the lungs. These mediators can reach the bloodstream, causing hematological and biochemical alterations (Brito 2014). However, these alterations were not evidenced, possibly due to the instillation time, and/ or protocol, or even in relation to the animal model used. Similarly, another study with nasal instillation of $\mathrm{PM}_{2.5}$ in rats also did not have alterations in the red blood cells count (Yi et al. 2017).

\section{Biochemical Parameters}

According to the biochemical data expressed in table 6 , no significant differences were observed 


\begin{tabular}{|c|c|c|c|}
\hline & Group 1 (CTL) & Group $2\left(\mathrm{PM}_{2.5}\right)$ & Group $3\left(\mathrm{PM}_{10}\right)$ \\
\hline Erythrocytes $\left(\mathrm{mm}^{3}\right)$ & $8.3 \times 10^{6} \pm 268214.2$ & $8.1 \times 10^{6} \pm 599837.0$ & $8.2 \times 10^{6} \pm 353712.0$ \\
\hline Hemoglobin ( $\mathrm{g} \%)$ & $14.30 \pm 0.4784$ & $14.28 \pm 0.4158$ & $14.12 \pm 0.5922$ \\
\hline Hematocrit (\%) & $44.66 \pm 1.5255$ & $45.54 \pm 1.6372$ & $43.77 \pm 1.7683$ \\
\hline $\operatorname{MCV}\left(\mathbf{U}^{3}\right)$ & $53.89 \pm 0.4864$ & $53.24 \pm 0.4624$ & $53.49 \pm 0.5152$ \\
\hline MCH (pg) & $17.25 \pm 0.2014$ & $17.22 \pm 0.2300$ & $17.21 \pm 0.2514$ \\
\hline MCHC (\%) & $32.02 \pm 0.1874$ & $32.26 \pm 0.2271$ & $32.21 \pm 0.2558$ \\
\hline Leukocytes $\left(\mathrm{mm}^{3}\right)$ & $70400 \pm 24631.50$ & $63900 \pm 16244.31$ & $64500 \pm 31099.30$ \\
\hline Platelets $\left(\mathrm{mm}^{3}\right)$ & $8.9 \times 10^{5} \pm 68555.65$ & $9.2 \times 10^{5} \pm 51633.75$ & $9.1 \times 10^{5} \pm 177835.87$ \\
\hline Segmented $\left(\mathrm{mm}^{3}\right)$ & $15.4 \pm 7.19$ & $14.8 \pm 4.46$ & $16.4 \pm 7.12$ \\
\hline Monocytes $\left(\mathrm{mm}^{3}\right)$ & $4.4 \pm 6.31$ & $6.5 \pm 4.76$ & $3.7 \pm 5.49$ \\
\hline Lymphocytes $\left(\mathrm{mm}^{3}\right)$ & $80.1 \pm 5.48$ & $76.7 \pm 9.45$ & $77.9 \pm 5.89$ \\
\hline
\end{tabular}

Tabla 5. Parámetros hematológicos. No hubo diferencias significativas ( $p>0.05$, ANOVA). MCV: Volumen corpuscular medio; MCH: Hemoglobina corpuscular media; MCHC: Concentración de hemoglobina corpuscular media. Los datos se expresan como media \pm desviación estándar; $\mathrm{n}=10$ animales por grupo.

Table 5. Hematological Parameters Results. There were no significant differences ( $p>0.05$, ANOVA). MCV: Mean corpuscular volume; MCH: Mean corpuscular hemoglobin; MCHC: Mean corpuscular hemoglobin concentration. Data are expressed as mean \pm standard deviation; $\mathrm{n}=10$ animals per group.

\begin{tabular}{|c|c|c|c|}
\hline & Group 1 (CTL) & Group $2\left(\mathrm{PM}_{2.5}\right)$ & Group $3\left(\mathrm{PM}_{10}\right)$ \\
\hline Glucose (mg/dL) & $237.6 \pm 44.36$ & $224.8 \pm 33.27$ & $268.3 \pm 59.79$ \\
\hline Total Cholesterol (mg/dL) & $62.6 \pm 5.35$ & $65.3 \pm 5.39$ & $64.1 \pm 5.23$ \\
\hline HDL (mg/dL) & $23.7 \pm 2.58$ & $23.2 \pm 1.75$ & $25.7 \pm 1.88$ \\
\hline Triglycerides (mg/dL) & $108.4 \pm 38.93$ & $87.6 \pm 25.10$ & $91.3 \pm 23.74$ \\
\hline
\end{tabular}

Tabla 6. Resultado de parámetros bioquímicos. No hubo diferencias significativas ( $>$ > 0.05, ANOVA). Los datos se expresan como media \pm desviación estándar; $\mathrm{n}=10$ animales por grupo.

Table 6. Biochemical parameters results. There were no significant differences $(\mathrm{p}>0.05$, ANOVA). Data are expressed as mean \pm standard deviation. $\mathrm{n}=10$ animals per group.

in the analyses of the biochemical parameters beween the groups, which agree with another study performed by Yan et al. (2014). These results suggest that the negative effects caused by the particulate matter are from neurological order and not systemic.

Therefore, new studies should be performed to comprehend the behavioral and biochemical mechanisms and their association with air pollution.

\section{Conclusions}

Particulate matter is one of the most harmful pollutants that are present in our atmosphere, composed of coarse and fine particles, which cause neurological diseases and pulmonary reactions. These particles are launched daily in the open air and carried by air currents, then these fractions can be inhaled and deposited in the lower and upper respiratory system.

The coarse fraction, characterized by $\mathrm{PM}_{10}$, is retained in the upper airways when inhaled and the body is responsible for eliminating it through sneeze and nasal cleaning. The fine fraction, which is classified as $\mathrm{PM}_{2.5}$, has high toxicity, capable of depositing in the lower respiratory system, in the alveolus region which are small structures that perform the gas exchange.

These alterations were perceived throughout this study, during the evaluation of locomotion and anxiety, which demonstrated that the rats were less anxious, because they remained most of the time in the open arms. This permanence in the open arms probably occurred because the animals presented respiratory difficulties, which lead to a 
decrease in the locomotion and, not necessarily due to an absence of anxiety. Regarding the hematological and biochemical parameters, no alterations were observed in the animals exposed to $\mathrm{PM}_{2.5}$ and $\mathrm{PM}_{10}$. From these results, we can conclude that the particulate matter when was inhaled by the rats caused some alterations in their behavior, however, no blood alterations were observed, which can be related to the time of exposure. Therefore, the behavioral alterations were associated with air pollution, nevertheless, more studies involving particulate matter are necessary to comprehend the risks that these pollutants can cause in health.

\section{References}

Adachi K \& Tainosho Y. 2004. Characterization of heavy metal particles embedded in tire dust. Environment International 30: 1009-1017. doi: https://doi.org/10. 1016/j.envint.2004.04.004.

Alleman LY, Lamaison L, Pedrix E, Robache A \& Galloo JC. 2010. PM10 metal concentrations and source identification using positive matrix factorization and wind sectoring in a French industrial zone. Atmospheric Research 96(4): 612-625. doi: https://doi. org/10.1016/j.atmosres. 2010.02.008.

Alves DD, Osório DMM, Rodrigues MAS, Illi JC, Bianchin, L \& Benvenuti T. 2015. Concentrations of PM2.5-10 and PM2.5 and metallic elements around the Schmidt Stream area, in the Sinos River Basin, southern Brazil. Brazilian Journal of Biology 75(4): 43-52. doi: http://dx.doi.org/10.1590/1519-6984. 00113suppl.

Behbehani MM. 1995. Functional characteristics of the midbrain periaqueductal gray. Progress in Neurobiology 46 (6): 575-605. doi: https://doi.org/10.1016/ 0301-0082(95) 00009-K.

Benarroch EE. 2012. Periaqueductal gray: an interface for behavioral control. Neurology 78: 210-217. doi: https://doi. org/10.1212/WNL.0b013e31823fcdee.

Binoki D. 2010. Alterações cardiopulmonares induzidas em ratos saudáveis após a instilação nasal subcrônica de suspensão aquosa de material particulado fino em concentração ambiental. São Paulo, Brasil: Universidade de São Paulo. Doctoral Thesis.

Block ML \& Calderón-Garcidueñas L. 2009. Air pollution: mechanisms of neuroinflammation and cns disease. Trends in Neuroscience 32 (9): 506-516. doi: https://doi. org/10.1016/j.tins.2009.05.009.

Braga A, Pereira LAA, Böhm GM \& Saldiva PHN. 2001. Poluição atmosférica e seus efeitos na saúde humana. Revista USP 51: 58-71.

Brito JM. 2014. Avaliação da exposição aguda às partículas urbanas concentradas e da exaustão de motores diesel e biodiesel sobre o perfil inflamatório pulmonar e sistêmico de camundongos. São Paulo,140 p. Programa de patologia da faculdade de medicina da Universidade de São Paulo. Doctoral Thesis.
Carobrez AP \& Bertoglio LJ. 2005. Ethological and temporal analyses of anxiety-like behavior: The elevated plus-maze model 20 years on. Neuroscience and Biobehavioral Reviews 29: 1193-1205. doi: https:// doi.org/10.1016/j.neubiorev.2005.04.017.

Carrive P. 1993. The periaqueductal gray and defensive behavior: functional representation and neuronal organization. Behavioural Brain Research 58: 27-47. doi: https://doi.org/10.1016/0166-4328(93)90088-8.

Carrive P \& Morgan MM. 2012. Periaqueductal gray. The Human Nervous System. $3^{a}$ ed. San Diego: Academic Express.

Chithra VS \& Nagendra SM. 2013. Chemical and morphological characteristics of indoor and outdoor particulate matter in an urban environmental. Atmospheric Environment 77: 579-587. doi: https://doi. org/10.1016/j.atmosenv. 2013.05.044.

Costa LG, Cole TB, Coburn J, Chang YC, Dao K \& Roqué PJ. 2017. Neurotoxicity of traffic-related air pollution. Neurotoxicology 59: 133-139. doi: https:// doi.org/10. 1016/j.neuro.2015.11.008.

Depaulis A \& Bandler R. 1991. The midbrain periaqueductal gray matter: functional, anatomical, and neurochemical organization. New York: Springer Science + Business Media.

Donaldson K, Stone V, Clouter A \& Macnee W. 2001. UItrafine particles. Occupational Environmental Medicine 58 (3): 211-216. doi: http://dx.doi.org/10. 1136/oem.58.3.211.

Dubowsky SD. 2006. Diabetes, obesity and hypertension may enhance associations between air pollution and markers of systemic inflammation. Environmental Health Perspectives 114(7): 992-998. doi: https://doi.org/10. 1289/ehp.8469.

Espinoda AJF, Rodríguez MT, De La Rosa FJB \& Sánchez JCJ. 2001. Size distribution of metals in urban aerosols in Seviller (Spain). Atmospheric Environment 35(14): 2595-2601. doi: https://doi.org/10. 1016/S1352-2310(00)00403-9.

Fernandes JS, Carvalho AM, Campos JF, Costa LO \& Filho GB. 2010. Poluição atmosférica e efeitos respiratórios, cardiovasculares e reprodutivos na saúde humana. Revista Médica de Minas Gerais 20(1): 92101.

Guerra FP \& Miranda RM. 2011. Influência da meteorologia na concentração do poluente atmosférico PM2,5 na RMRJ e na RMSP. Instituto Brasileiro de Estudos Ambientais: II Congresso Brasileiro de Gestão Ambiental. Available in https://www.ibeas.org.br/ congresso/Trabalhos2011/IV-007.pdf (accessed on 1-VIII-2019).

Hogg S. 1996. A review of the validity and variability of the elevated plus-maze as an animal model of anxiety. Pharmacology Biochemistry and Behavior 54: 21-30. doi: https://doi.org/10.1016/0091-3057(95) 02126-4.

Holstege G. 2014. The periaqueductal gray controls brainstem emotional motor systems including respiration. Progress Brain Research 209: 379-405. doi: https://doi.org/10. 1016/B978-0-444-63274-6.000205.

Hieu N \& Lee BK. 2010. Characteristics of particulate matter and metals in the ambient air from a residen- 
tial area in the largest industrial city in Korea. Atmospheric Research 98(2-4): 526-537. doi: https://doi. org/10.1016/j.atmosres. 2010.08.019.

Kabata-Pendias A \& Mukherjee AB. 2007. Trace elements from soil to human. Springer Science \& Business Media.

Keay K \& Bandler R. 2004. Periaqueductal gray. The Rat Nervous System. $3^{a}$ ed. San Diego: Elsevier Academic Press.

Lim JM, Lee JH, Moon JH, Chung YS \& Kim KH. 2010. Airborne PM10 and metals from multifarious sources in an industrial complex area. Atmospheric Research 96: 53-64. doi: https://doi.org/10.1016/j.atmosres. 2009.11.013.

Linnman C, Moulton EA, Barmettler G, Becerra L \& Borssok D. 2012. Neuroimaging of the periaqueductal gray: state of the field. Neuroimage 60(1): 505522. doi: https://doi.org/10.1016/j.neuroimage. 2011. 11.095.

Loyola AG, Quitero SL, Escaleira V \& Minho AS. 2012. Trace metals in the urban aerosols of Rio de Janeiro city. Journal of the Brazilian Chemical Society 23(4): 628-638. doi: https://doi.org/10.1590/S0103$\underline{50532012000400007}$.

Luo B, Liu J, Fei G, Han T, Zhang K, Wang L, ... Niu J. 2017. Impact of probable interaction of low temperature and ambient fine particulate matter on the function of rats alveolar macrophages. Environmental Toxicology and Pharmacology 49:172-178. doi: https://doi.org/10.1016/j. etap.2016.12.011.

Manahan SE. 2013. Química ambiental. 9a ed., São Paulo: bookman.

Mazzoli-Rocha F, Carvalho, GM, Lanzetti M, Valença SS, Silva LF, Saldiva PH, ... Faffe DS. 2014. Respiratory toxicity of repeated exposure to particles produced by traffic and sugar cane burning. Respiratory Physiology Neurobiology 191: 106-113. doi: https:// doi. org/10.1016/j.resp. 2013. 11.004.

Mello PAS, Zamboni W, Mariani RL \& Sella SM. 2010. Caracterização do material particulado fino e grosso e composição da fração inorgânica solúvel em água em São José dos Campos (SP). Química Nova 33 (6): 1247-1253. doi: https://doi.org/10.1590/S010040422010000600005.

Migliavacca DM, Teixeira EC, Gervasoni F, Conceição RV \& Rodriguez MTR. 2012. Metallic elements and isotope of $\mathrm{Pb}$ in wet precipitation in urban area, South America. Atmospheric Research 107: 106114. doi: https://doi.org/10. 1016/j.atmosres.2012. $\underline{01.001 .}$.

Nahas TR. 1999. O teste do campo aberto. In: Xavier G.T. (editor), Técnicas para o estudo do sistema nervoso. São Paulo: Editora Plêiade.

Nicodemos RM, Jesus AR, Fontoura RS \& Barrozo MAS. 2009. Estudo da relação entre variáveis meteorológicas e concentração de MP10 no centro da cidade de Uberlância (MG). Anais de Congresso brasileiro de Engenharia Química. Available in https:// ss|4799.websiteseguro.com/swge5/seg/cd2008/PDF IIC2008-0021.PDF (accessed on 1-VIII-2019).

Rojas-Carvajal M, Fornaguera J, Mora-Gallegos A \& Brenes JC. 2018. Testing experience and environmental enrichment potentiated open-field habituation and grooming behavior in rats. Animal Behaviour 137: 225-235. doi: https://doi.org/10.1016/j.anbehav.2018.01.018.

Seinfeld JH \& Pandis SN. 2006. Atmospheric chemistry and physics: from air pollution to climate change. New York: John Wiley \& Sons.

Thorpe A \& Harrison RM. 2008. Sources and properties of non-exhaust particulate matter from road traffic: A review. Science of the Total Environment 400: 270282. doi: https://doi.org/10.1016/j.scitotenv.2008.06. $\underline{007}$.

Unsal AIA, Basal Y, Birincioglu S, Koracturk T, Cakmak $H$, Unsal A, ... Demirci B. 2018. Ophtalmic adverse effects of nasal decongestants on an experimental rat model. Arquivos Brasileiros de Oftalmologia 81(1); 53-58. doi: http://dx.doi.org/10.5935/00042749.20180012.

Xu HM, Cao JJ, Ho KF, Ding H, Han YM, Wang GH, Chow JC, ... Li WT. 2012. Lead concentrations in fine particulate matter after the phasing out of leaded gasoline in Xi'an, China. Atmospheric Environment 46(23): 217-224. doi: https://doi.org/ 10.1016/j.atmosenv.2011.09.078.

Yan Y-H, Chou CC-K, Wang J-S, Tung C-L, Li Y-R, Lo K, Cheng T-J. 2014. Subchronic effects of inhaled ambient particulate matter on glucose homeostasis and target organs damage in a type 1 diabetic rat model. Toxicology and Applied Pharmacology 281:211-220. doi: https://doi.org/10.1016/j.taap.2014.10.005.

Yi L, Wei C \& Fan W. 2017. Fine-particulate matter (PM2.5), a risk factor for rat gestational diabetes with altered blood glucose and pancreatic GLUT2 expression. Gynecological Endocrinology 33(8): 611-616. doi: https://doi.org/10.1080/09513590. 2017.1318368.

Wang Y, Xiong L \& Tang M. 2017. Toxicity of inhaled particulate matter in the central nervous system: neuroinflammation, neuropsychological effects and neurodegenerative disease. Journal of Applied Toxicology 37:644-667. doi: https://doi.org/10.1002/jat. $\underline{3451}$. 